\title{
Seaweed Bioethanol Production: A Process Selection Review on Hydrolysis and Fermentation
}

\author{
Felix Offei ${ }^{1, *}$, Moses Mensah ${ }^{2}$, Anders Thygesen ${ }^{3} \mathbb{D}$ and Francis Kemausuor ${ }^{1}$ (D) \\ 1 Department of Agricultural and Biosystems Engineering, Kwame Nkrumah University of Science and \\ Technology, AK-449-1916 Kumasi, Ghana; kemausuor@gmail.com \\ 2 Department of Chemical Engineering, Kwame Nkrumah University of Science and Technology, \\ AK-449-1916 Kumasi, Ghana; mymens14@gmx.com \\ 3 Department of Biotechnology and Biomedicine, Technical University of Denmark, \\ DK2800 Lyngby, Denmark; athy@dtu.dk \\ * Correspondence: felixaug4@gmail.com; Tel.: +233-267-766-644
}

Received: 31 October 2018; Accepted: 27 November 2018; Published: 29 November 2018

\begin{abstract}
The rapid depletion and environmental concerns associated with the use of fossil fuels has led to extensive development of biofuels such as bioethanol from seaweeds. The long-term prospect of seaweed bioethanol production however, depends on the selection of processes in the hydrolysis and fermentation stages due to their limiting effect on ethanol yield. This review explored the factors influencing the hydrolysis and fermentation stages of seaweed bioethanol production with emphasis on process efficiency and sustainable application. Seaweed carbohydrate contents which are most critical for ethanol production substrate selection were $52 \pm 6 \%, 55 \pm 12 \%$ and $57 \pm 13 \%$ for green, brown and red seaweeds, respectively. Inhibitor formation and polysaccharide selectivity were found to be the major bottlenecks influencing the efficiency of dilute acid and enzymatic hydrolysis, respectively. Current enzyme preparations used, were developed for starch-based and lignocellulosic biomass but not seaweeds, which differs in polysaccharide composition and structure. Also, the identification of fermenting organisms capable of converting the heterogeneous monomeric sugars in seaweeds is the major factor limiting ethanol yield during the fermentation stage and not the SHF or SSF pathway selection. This has resulted in variations in bioethanol yields, ranging from $0.04 \mathrm{~g} / \mathrm{g}$ DM to $0.43 \mathrm{~g} / \mathrm{g}$ DM.
\end{abstract}

Keywords: seaweed; bioethanol; pre-treatment; hydrolysis; fermentation; enzymes

\section{Introduction}

Biofuels such as bioethanol, biodiesel, biogas and bio-butanol are currently advocated globally as eco-friendly and sustainable sources of energy. Bioethanol is the most widely used biofuel globally with the production of 106 billion litres in the year 2017 [1]. The most extensive use of bioethanol is as fuel for engines and as fuel additive [2]. Commercial bioethanol production has been limited to the use of edible feedstock such as sugarcane, corn, sweet sorghum and sugar beet (1st generation feedstock) [1]. This could potentially result in food security problems especially in many developing countries.

In view of this, research is targeting 2 nd and 3rd generation feedstock including crop residues and algae. Seaweed (macroalgae) is receiving considerable global attention as the primary source of 3rd generation biofuels [3-5]. The major advantages derived from the use of seaweeds over terrestrial lignocellulosic biomass (2nd generation) include no agricultural land usage and no resource input such as fertilizer, pesticides and water [6]. The low contents of recalcitrant compounds such as lignin in seaweeds, also makes enzymatic hydrolysis of seaweeds with little or no pre-treatment possible [7]. Carbon neutrality is another major advantage of seaweed bioethanol production, due to the favourable 
net $\mathrm{CO}_{2}$ emissions between seaweed bioethanol production and combustion and seaweed $\mathrm{CO}_{2}$ uptake during photosynthesis $[2,8]$. Seaweed is known to have a much higher photosynthetic efficiency (6-8\%) than terrestrial biomass (2\%) [9]. These advantages indicate that seaweed has considerable prospect as an eco-friendly and sustainable feedstock for bioethanol production.

Bioethanol is produced from the carbohydrate content of seaweed which constitutes $40-77 \%$ dry matter (DM) [10]. 50-70\% of the seaweed carbohydrates can often be converted to fermentable sugars [5]. Bioethanol has been produced from red seaweed species such as Kappaphycus sp. [11], Gelidium sp. [12] and Gracilaria sp. [8]; brown seaweed species such as Laminaria sp. [3] and Sargassum sp. [13,14] and; green seaweeds such as Ulva sp. [15,16], Chaetomorpha sp. [17] and Rhizoclonium sp. [8].

The production of bioethanol consists of the following stages: biomass pre-treatment, hydrolysis, fermentation and ethanol recovery $[14,18]$. The long-term commercial prospect of seaweed bioethanol production depends on the choice of methods especially in the hydrolysis and fermentation stages, due to their substantial overall effect on ethanol yield [18]. The efficiency of ethanol production is first limited by the amount of fermentable sugars released during the hydrolysis stage. The fermentation stage will then produce ethanol based on the available reducing sugars and the efficiency of the fermenting organism. The choice of methods in these two critical stages of seaweed bioethanol production should therefore be invariably efficient, cost-effective and sustainable especially for commercial scale production. The optimization of the hydrolysis and fermentation stages selected is also a major challenge in bioethanol production globally.

This review explores the hydrolysis and fermentation stages of seaweed bioethanol production with emphasis on process efficiency and sustainable application. The composition of seaweeds, hydrolysis treatment conditions and the effect of fermenting microorganisms applied so far to seaweed hydrolysates are also examined within the context of conversion efficiency.

\section{Composition of Sugars in Seaweeds}

Seaweeds are divided into three groups based on their pigmentation, namely Rhodophyceae (red seaweeds), Phaeophyceae (brown seaweeds) and Chlorophyceae (green seaweeds). The dominant pigments found in seaweed groups are r-phycoerythrin, chlorophyll and xanthophyll in the red, green and brown seaweeds, respectively [19]. Seaweeds are made up of carbohydrates, proteins, lipids and minerals. Table 1 shows the composition of recently studied seaweed species. It highlights the carbohydrate fraction as the most abundant ranging between 40 to $77 \%$ DM, followed by proteins (6-43\% DM) and minerals (ash content) (9-47\% DM). Generally, seaweeds contain large amounts of complex sulphated carbohydrates (polysaccharides) that are often extracted for use mainly in the hydrocolloid industry [8]. Each seaweed group uniquely consists of different types of complex polysaccharides serving as storage and supporting structural tissue such as the cell wall [20].

Table 1. Composition of selected seaweed species.

\begin{tabular}{|c|c|c|c|c|c|c|c|}
\hline $\begin{array}{l}\text { Seaweed } \\
\text { Type }\end{array}$ & Species & Carbohydrate & $\begin{array}{l}\text { Protein } \\
\text { (\% Dry }\end{array}$ & $\begin{array}{l}\text { Lipid } \\
\text { lass) }\end{array}$ & Ash & Country/Area $^{1}$ & Ref. \\
\hline \multirow{9}{*}{ Green } & Caulerpa lentillifera & 38.7 & 10.4 & 1.1 & 37.2 & $\begin{array}{l}\text { MY/North } \\
\text { Borneo }\end{array}$ & [21] \\
\hline & Chaetomorpha linum & 54 & - & - & 22 & DK/Roskilde & [17] \\
\hline & C. linum & 29.8 & 8.6 & 2.6 & 30.5 & TN/Tunis Lagoon & [22] \\
\hline & Codium fragile & 58.7 & 15.3 & 0.9 & 25.1 & S. Korea & [10] \\
\hline & Ulva fasciata & 43.0 & 14.4 & 1.8 & 16.0 & IN/Veraval & [15] \\
\hline & Ulva lactuca & 54.3 & 20.6 & 6.2 & 18.9 & S. Korea & [3] \\
\hline & Ulva pertusa & 52.3 & 25.1 & 0.1 & 22.5 & $\mathrm{KR} /$ Jeju Island & [23] \\
\hline & Ulva rigida & 53 & 23.4 & 1.2 & 21.7 & MA/Azla & [24] \\
\hline & Average & $52 \pm 6$ & $19 \pm 7$ & $1.4 \pm 1$ & $25 \pm 9$ & - & \\
\hline
\end{tabular}


Table 1. Cont

\begin{tabular}{|c|c|c|c|c|c|c|c|}
\hline $\begin{array}{c}\text { Seaweed } \\
\text { Type }\end{array}$ & Species & Carbohydrate & $\begin{array}{l}\text { Protein } \\
\text { (\% Dry } 1\end{array}$ & $\begin{array}{l}\text { Lipid } \\
\text { mass) }\end{array}$ & Ash & Country/Area ${ }^{1}$ & Ref. \\
\hline \multirow{13}{*}{ Red } & Chondrus pinnulatus & 64.4 & 22.5 & 0.2 & 12.9 & KR/Ganganri & [25] \\
\hline & Cryptonemia crenulata & 47 & - & - & 19 & GH/Prampram & [26] \\
\hline & Kappaphycus alvarezzi & 60.7 & 17.4 & 0.8 & 21.1 & IN/Bhavnagar & [27] \\
\hline & K. alvarezzi & 55 & & & 23 & VN/Nha Trang & [26] \\
\hline & Eucheuma cottonii & 26.5 & 9.8 & 1.1 & 46.2 & Malaysia & [21] \\
\hline & Gelidium amansii & 66.0 & 20.5 & 0.2 & 13.3 & S. Korea & [10] \\
\hline & Gigartina tenella & 42.2 & 27.4 & 0.9 & 24.5 & KR/Songdo & [25] \\
\hline & Hypnea charoides & 57.3 & 18.4 & 1.5 & 22.8 & CN/Hong Kong & [28] \\
\hline & Hypnea musciformis & 39 & - & - & 22 & GH/Old Ningo & [26] \\
\hline & H. musciformis & 37 & - & - & 30 & GH/Prampram & [26] \\
\hline & Hydropuntia dentata & 39 & - & - & 36 & GH/Prampram & [26] \\
\hline & Lomentaria hakodatensis & 40.4 & 29 & 0.7 & 29.9 & KR/Ganganri & [25] \\
\hline & Average & $57 \pm 13$ & $22 \pm 10$ & $1 \pm 0.8$ & $20 \pm 7$ & - & \\
\hline \multirow{9}{*}{ Brown } & Laminaria digitata (April) & 16.6 & 9.3 & 0.7 & 31.0 & Denmark & [29] \\
\hline & L. digitata (August) & 64.2 & 3.1 & 1.0 & 11.9 & Denmark & [29] \\
\hline & Laminaria japonica & 51.9 & 14.8 & 1.8 & 31.5 & S. Korea & [3] \\
\hline & L. japonica & 51.5 & 8.4 & 1.3 & 38.8 & S. Korea & [10] \\
\hline & Sargassum fulvellum & 39.6 & 13 & 1.4 & 46 & S. Korea & [3] \\
\hline & Sargassum polycystum & 33.5 & 5.4 & 0.3 & 42.4 & Malaysia & [21] \\
\hline & Sargassum vulgare & 61.6 & 13.6 & 4.9 & 19.4 & - & [23] \\
\hline & Saccharina latissima (April) & 16.8 & 10.1 & 0.5 & 34.6 & Denmark & [29] \\
\hline & Average & $55 \pm 12$ & $12 \pm 5$ & $1.7 \pm 1.4$ & $31 \pm 12$ & & \\
\hline
\end{tabular}

\subsection{Green Seaweed (Chlorophyceae)}

The total carbohydrate content in green seaweeds range between $45 \%$ for C. lentillifera and $59 \%$ for C. fragile (Table 1). It consists mainly of the polysaccharides; ulvan, starch and cellulose (Table 2) [30]. Ulvan consists of various oligosaccharide units of L-rhamnose-3-sulfate, D-xylose-2-sulfate and various units of uronic acids [23]. It is found mainly in species belonging to the genera, Ulva. It is water soluble with a wide range of applications in food, pharmaceutical and chemical industries but faces stiff competition from other highly viscous hydrocolloids such as alginate and agar from brown and red seaweeds, respectively [31].

Starch and cellulose found in green seaweeds and plants, in general, are both made up of glucose units in their monomeric form but are unique in their configuration. Their difference is found in their anomeric carbon (C1) configuration, which is $\beta$ - in cellulose and $\alpha$-in starch [32]. Cellulose has a regular linear chain with 1,4- $\beta$-glycosidic linkages in parallel linear arrays forming a stable crystalline structure [33]. It has a stable chain with hydrogen and Van der Waal bonds making them strong and very resistant to enzymatic and physical breakdown. Starch conversely, has an open and loosely bonded helical configuration, which makes it easier to solubilize with enzymes, chemicals or through physical degradation [33].

Table 2. Composition of sugars in seaweed.

\begin{tabular}{|c|c|c|c|}
\hline \multirow[t]{2}{*}{ Component } & \multicolumn{3}{|c|}{ Type of Seaweed } \\
\hline & $\begin{array}{l}\text { Chlorophyceae } \\
\text { (Green) }[30,34]\end{array}$ & $\begin{array}{l}\text { Rhodophyceae } \\
\text { (Red) }[26,30]\end{array}$ & $\begin{array}{l}\text { Phaeophyceae } \\
\text { (Brown) [35-37] }\end{array}$ \\
\hline Polysaccharide & $\begin{array}{c}\text { Cellulose } \\
\text { Ulvan } \\
\text { Starch }\left(\text { Glu }_{(\alpha-1,3)+(\alpha-1,6)}\right) \\
\text { Mannan Xyloglucan }\end{array}$ & $\begin{array}{c}\text { Cellulose }(10 \%)\left(\mathrm{Glu}_{(\beta-1,4)}\right) \\
\text { Agarose }(\mathrm{Gal}-\mathrm{LAHGal})_{\mathrm{n}} \\
\text { Carrageenan }\left(\mathrm{Gal}-\mathrm{DAHGal} \mathrm{CH}_{((\beta-1,4)+\beta-1,4)}\right) \\
\text { Starch }(1-10 \%)\end{array}$ & $\begin{array}{c}\text { Laminarin }\left(\operatorname{Glu}_{(\beta-1,3)+(\beta-1,6)}\right) \\
\text { Mannitol } \\
\text { Alginate }(\operatorname{ManA}+\operatorname{GulA}) \\
\text { Fucoidan }\left(\operatorname{Fuc}_{(\alpha-1,3)}\right)\end{array}$ \\
\hline $\begin{array}{l}\text { Major } \\
\text { monosaccharides, } \\
\text { sugar alcohols, } \\
\text { uronic acids }\end{array}$ & $\begin{array}{c}\text { Glucose } \\
\text { Mannose } \\
\text { Uronic acid } \\
\text { Rhamnose } \\
\text { Xylose } \\
\text { Glucoronic acid }\end{array}$ & $\begin{array}{c}\text { Glucose }(11-18 \%) \\
\text { Galactose }(15-30 \%)\end{array}$ & $\begin{array}{c}\text { Glucose }(6-51 \%) \\
\text { Fucose }(2-6 \%) \\
\text { Mannitol }(4-10 \%) \\
\text { Mannuronic acid }(9-17 \%) \\
\text { Guluronic acid }(8-16 \%)\end{array}$ \\
\hline
\end{tabular}


Table 2. Cont.

\begin{tabular}{|c|c|c|}
\hline Component & Type of Seaweed & \\
\hline Minor components $^{1}$ & $\begin{array}{c}\text { Lignin + Man + Rha + Ara + Xyl + GluA + } \\
\text { GulA + GalA }\end{array}$ & $\begin{array}{c}\mathrm{Rha}+\mathrm{Ara}+\mathrm{Gal}+\mathrm{Xyl}+ \\
\mathrm{Man}+\mathrm{GluA}\end{array}$ \\
\hline Pigments & r-phycoerythrin & Xanthophyll \\
\hline
\end{tabular}

\subsection{Red Seaweed (Rhodophyceae)}

The total carbohydrate content in red seaweeds range between $27 \%$ for E. cottonii and $66 \%$ for G. amansii (Table 1). This is composed mainly of the polysaccharides; carrageenan (found only carrageenopytes), agar (found only in agarophytes) and cellulose (Table 2) [38]. Agar is made up of hydrophilic galactans consisting of L-galactopyranose units with alternating $\alpha-1,3$ and $\beta-1,4$ linkages, whereas the $\alpha$-linked galactopyranose is in the D-configuration of carrageenans [38]. Commercially, agar is produced from various species of Gelidium and Gracilaria. The simplest method of obtaining agar in these species is by heating the seaweed in water for several hours. The agar dissolves into solution and is obtained through filtration to remove seaweed residue [39]. It is used predominantly in the food industry but also has some microbiological and pharmaceutical uses.

Carrageenan found in carrageenophytes also contains linear sulphated galactans with alternating and repeating oligosaccharide units of 3-linked $\beta$-D-galactopyranose and 5-linked $\alpha$-D-galactopyranose [32]. Carrageenan is extracted commercially in several species of Kappaphycus, Chondrus and Eucheuma. There are different types of carrageenans based on their unique structure and gelling properties. They are, iota which forms elastic gels with calcium salts, kappa which forms rigid gels with potassium salts and lambda which forms a viscous solution without gels [39]. Hybrid carrageenans can be selectively extracted using enzymes. This can allow for targeted production of specific gelation properties since hybrid carrageenans exhibit distinctive physical properties. Commercial cellulase enzymes have proved useful for their hydrolysis [38]. Carrageenans are used in the food industry particularly in dairy products and in enzyme immobilization.

\subsection{Brown Seaweed (Phaeophyceae)}

The total carbohydrate content in brown seaweeds range between $40 \%$ for species such as S. fulvellum and $64 \%$ for L. digitata (Table 1 ). It is composed of polysaccharides such as laminarin, mannitol, cellulose, alginate and fucoidan (Table 2). Laminarin has a $\beta-1,3$ glucan chain forming the major storage polysaccharide in brown seaweed [40]. It occasionally has $\beta-1,3$ linkages with a polymerization degree length of up to 25 mostly in kelps (Laminaria sp.) [41]. Mannitol is a sugar alcohol formed by reduction of mannose [41]. It performs an osmoregulatory function in brown seaweed [19]. The concentrations of laminarin and mannitol are known to vary throughout the year. In a study using the L. digitata species of the brown seaweed, both sugars were found in low concentrations fewer than 5\% DM in the early part of the year (January to April) but peaked in June and July at 32 and $24.6 \%$ DM for mannitol and laminarin, respectively [41]. These values declined steadily in the later part of the year (August to December). This rise and fall within the year seem to correspond with the weather changes in the seasons; concentrations are lowest in the winter and highest in the summer. This can be attributed to the abundant sunshine available for the formation of cellular storage tissue in the summer and; the usage of these storage tissues during the winter [41]. Laminarin can be enzymatically hydrolysed by laminarinase (endo-1,3(4)- $\beta$-glucanase) and cellulases (endo-1,4(4)- $\beta$-glucanase) to release its glucose monomers [42]. Mannitol, however, must first be oxidized to fructose by a mannitol dehydrogenase before its monomer units can be recovered [19].

Alginate, also known as alginic acid, is found in the cell wall of brown seaweeds and is made up of repeating chains of guluronic acids and mannuronic acids [32]. Alginates can form up to $50 \%$ of the carbohydrate fraction in brown seaweeds and are considered essential in maximizing the 
recovery of bioethanol during yeast fermentation [43]. They are made up of linear co-polymers of the uronates, $\beta$-D-mannuronate and $\alpha$-L-guluronate, which are linked by 1,4-glucosidic bonds in various sequential arrangements [44].

Fucoidans in brown seaweeds consists mainly of L-fucose and sulphated ester groups including sulphated fucogalacturonans found in species of Sargassum and Laminaria [45]. This polysaccharide has been extensively studied for its antioxidant, anticoagulant, antiviral, therapeutic and other beneficial biological and pharmacological properties [32]. Fucoidan has been isolated from various species of Undaria, Laminaria and Sargassum. The biochemical analysis of the dry matter of Laminaria hyperborea in a study, found 0-30\% laminarin, 4-25\% mannitol and $17-34 \%$ alginate [46].

\section{Seaweed Biomass Handling and Pre-Treatment}

The handling of seaweed biomass after harvesting is very important since poor handling can lead to seaweed decay during transportation and storage. Also, contamination by impurities including sand, aquatic plants and animals can lead to changes in the biomass composition. The major handling and pre-treatment processes therefore used after seaweed harvesting are washing, drying and grinding.

Seaweed after collection is often washed with water to remove stones, sand and other undesirable impurities [8,47]. In a study which considered the effect of washing, it was observed that there is significant loss of carbohydrates of up to $49 \%$ laminarin in L. digitata when washed rapidly under tap water [48]. Despite these losses the combined effect of debris, sand and salts in process streams especially for commercial scale bioethanol production is undesirable. Washing at source with seawater may be a preferable option to conserve fresh water. This makes it a more cost-effective and sustainable option.

Drying of seaweed is a major and energy-consuming handling process in bioethanol production because the moisture content in freshly harvested seaweed is enormous (85-90\%) [49]. Methods that have been used in drying seaweeds include freeze-drying [43], sun drying [44] and oven drying [50]. In a study comparing the effect of various drying methods on the composition of L. digitata, it was observed that the content of laminarin, the primary carbohydrate in brown seaweeds, was $10.9 \%$, $10.8 \%$ and $14.7 \%$ (g/100 g dry solid) for oven dried, frozen-oven dried and freeze-dried seaweed, respectively [48,51]. These results recommend freeze-drying as a viable option but its economic benefits would have to be compared to conclusively choose it as a sustainable option. Also, the application of freeze drying may not be feasible for seaweed farmers, who are predominantly from poor coastal communities, due to the high cost of energy required.

Sun drying, which is currently most convenient for seaweed farmers, is an alternative drying method which has been used in several studies [44,52]. Apart from the observed loss of seaweed pigmentation or de-colorization, its effect on seaweed carbohydrate composition is yet to be investigated. Concerns over compositional changes may be valid since sun drying is not as well-controlled as oven drying. Its low cost remains an important consideration in process selection. The use of non-dried seaweed is currently not considered since commercial bioethanol production can only be sustained if the seaweed is stored and transported to processing plants in the dry form to minimize microbial decay and transportation costs. However, if the cultivation site can adequately supply a bioethanol plant nearby, matching the feed rate, the drying step can be avoided.

Size reduction or milling is also a critical handling and pre-treatment method, which increases the surface area of the biomass especially for the action of catalysts in the hydrolysis and fermentation stages [44]. Size reduction also reduces the bulk volume of the seaweed enhancing the efficiency of transportation and storage. Milling has been noted to have some hydrolytic effect on seaweed biomass when applied [17].

\section{Hydrolysis of Seaweeds}

The hydrolysis process of bioethanol production involves the breakdown of complex sugars (carbohydrates) such as laminarin, cellulose, mannitol, alginate, ulvan, carrageenan and agar in 
seaweeds to simple sugars such as glucose, galactose, mannose, fucose, xylose and arabinose for fermentation to ethanol [53]. Various treatments have been used during hydrolysis of seaweed for bioethanol production. These treatments include dilute acid thermal [20,54,55], dilute alkaline thermal [15,56], enzymatic [50,57,58], thermal [55,59], ball milling [17], hydrothermal (HTT) [17] and ultrasound [60]. These are usually grouped into physical, chemical, thermal and enzymatic treatments. Two or more of these treatments are also combined in some studies to maximize yield [11,50]. To date however, there has been no study on the effect of each hydrolysis method on the different groups of seaweed to determine, which method is most suited to a particular group of algae. The succeeding sections discuss these methods in detail with emphasis on efficiency and sustainable use.

\subsection{Dilute Acid Thermal Hydrolysis}

Dilute acid thermal hydrolysis is the most extensively used treatment in seaweed bioethanol research, since it is considered cost-effective with a shorter reaction time than current hydrolysis methods used [61]. Strong acids such as $\mathrm{H}_{2} \mathrm{SO}_{4}$ and $\mathrm{HCl}$ have been the most extensively used chemical catalysts for the hydrolysis of seaweeds [5,50,62,63]. A major drawback from the use of acid catalysts is the production of inhibitors in the form of 5-hydroxymethylfurfural (5-HMF), furfural and levulinic acid $[63,64]$. These inhibitors are formed from the dehydration of hexoses (C6 reducing sugars) and pentoses (C5 reducing sugars), which is caused by high acid concentrations and long retention times [63]. The inhibitors can hinder the fermentation of reducing sugars by damaging the DNA and, impeding protein and RNA synthesis of fermenting organisms such as yeast [64]. The use of activated carbon to filter hydrolysates before fermentation has been effectively used to reduce the concentration of inhibitors [11,65]. In the study by Hargreaves et al. [11], an initial 5-HMF concentration of $30 \mathrm{~g} / \mathrm{L}$ was reduced to $5 \mathrm{~g} / \mathrm{L}$, when acid hydrolysates from $\mathrm{G}$. amansii were filtered through an activated carbon bed. Alternatively, a yeast strain called Pichia stipitis KCTC 7228, has been found capable of converting furfural to furfuryl alcohol and 5-HMF to 2,5-bis-hydroxymethylfuran [64]. These products were found to have no effect on glucose fermentation when formed and accumulated in solution.

The dilute acid hydrolysis method is considered more cost-effective in comparison to the use of enzymes and other methods primarily because there is a well-established market for the production and use of strong acid catalysts. Costs are also further reduced since the catalysts are used in low concentrations of 0.01-0.90 M [15,50]. The costs are however increased by a neutralization step preceding fermentation to provide optimal conditions for the fermenting organism. Minimal concentrations and volumes of bases are nonetheless used in the neutralization. The claim of dilute acid treatment being cost-effective in comparison to other hydrolysis methods, therefore, has some merit.

Various dilute acid hydrolysis conditions have been used in various studies to obtain variable reducing sugar yields (Table 3). This has led to repeated optimization by researchers studying different species of seaweed to maximize the yield of fermentable reducing sugars [14,65]. Parameters often considered during dilute acid hydrolysis optimization are the substrate concentration, reaction time, reaction temperature and catalyst concentration. Interestingly, very few of these studies have had optimization conditions that are similar even though variables studied were the same. These differences could be attributed to several factors, namely differences in seaweed species used, types of carbohydrates in each species and seasonal composition variation in similar species [41]. Polysaccharides in red, green and brown seaweeds have been known to differ enormously (Table 2). The hydrolytic reactions between acids and the various glycosidic linkages in polysaccharides may therefore differ.

The sustainable use of acid catalysts faces a further challenge in catalyst recovery since they cannot be removed from any of the process streams. They can, however, be regenerated from the salts formed with bases during neutralization. Regeneration to their individual acids and bases is rather costly, which makes acid recovery and reuse less viable. Overall, seaweed hydrolysis with acid catalysts seems rather promising due to its appreciable efficiency and economics. However, its effect 
on the environment largely from the toxicity of acid catalysts and the disposal of the salts recovered after distillation makes it less sustainable.

Table 3. Comparison of dilute acid hydrolysis conditions and their sugar yields.

\begin{tabular}{|c|c|c|c|c|c|c|c|c|}
\hline \multirow{2}{*}{$\begin{array}{c}\text { Seaweed } \\
\text { (Type of Seaweed) }\end{array}$} & \multirow{2}{*}{$\begin{array}{c}\mathrm{DM} \\
\% v / w\end{array}$} & \multicolumn{3}{|c|}{ Dilute Acid Treatment } & \multicolumn{3}{|c|}{ Sugar Released (mg/g DM) ${ }^{1}$} & \multirow[b]{2}{*}{ Ref. } \\
\hline & & $\begin{array}{l}\text { Conc. } \\
\text { (M) }\end{array}$ & $\begin{array}{l}\text { Temp. } \\
\left({ }^{\circ} \mathrm{C}\right)\end{array}$ & $\begin{array}{l}\text { Time } \\
\text { (min) }\end{array}$ & RSu & Glu & Gal & \\
\hline $\begin{array}{l}\text { U. lactuca } \\
\text { (green) }\end{array}$ & 10 & 0.5 & 121 & 15 & 119 & 53 & 8 & {$[5]$} \\
\hline $\begin{array}{l}\text { Fucus serratus } \\
\text { (brown) }\end{array}$ & 10 & 0.5 & 121 & 15 & 111 & 10 & 9 & {$[5]$} \\
\hline $\begin{array}{l}\text { K. alvarezii } \\
\text { (red) }\end{array}$ & 10 & 0.2 & 130 & 15 & 305 & & 256 & {$[66]$} \\
\hline $\begin{array}{l}\text { G. amansii } \\
\text { (red) }\end{array}$ & 10 & 0.2 & 130 & 15 & 292 & & 200 & [65] \\
\hline $\begin{array}{l}\text { Gracilaria tenuistipitata } \\
\text { (red) }\end{array}$ & 10 & 0.2 & 130 & 15 & 266 & & 187 & {$[65]$} \\
\hline $\begin{array}{l}\text { Gracilaria chorda } \\
\text { (red) }\end{array}$ & 10 & 0.2 & 130 & 15 & 234 & & 136 & [65] \\
\hline $\begin{array}{l}\text { Palmaria palmata } \\
\text { (red) }\end{array}$ & 10 & 0.4 & 125 & 25 & 218 & 27 & 128 & [67] \\
\hline $\begin{array}{l}\text { G. tenuistipitata } \\
\text { (red) }\end{array}$ & 0.0004 & 2 & 100 & 900 & 539 & 36 & 275 & [8] \\
\hline $\begin{array}{l}\text { Ulva intestinalis } \\
\text { (green) }\end{array}$ & 0.0004 & 2 & 100 & 900 & 50 & 14 & 5 & {$[8]$} \\
\hline $\begin{array}{l}\text { Undaria pinnatifida } \\
\text { (brown) }\end{array}$ & 13 & 0.075 & 121 & 60 & 220 & & & {$[43]$} \\
\hline $\begin{array}{c}\text { Amphiroa fragilissima } \\
\text { (red) }\end{array}$ & 10 & 0.2 & 121 & 15 & 73 & & 44 & [67] \\
\hline
\end{tabular}

${ }^{1}$ RSu: Reducing sugar, Glu: Glucose, Gal: Galactose.

\subsection{Dilute Alkaline Thermal Hydrolysis}

Dilute alkaline thermal hydrolysis is the direct alternative to dilute acid hydrolysis. In this case, a base is used as a catalyst in place of the acid. Studies on the use of bases in seaweed hydrolysis are quite few [56-68]. This could be due to the larger base concentrations required to achieve efficiencies as high as acid catalysts [57,68]. Also, at high temperatures and longer reaction times, hydroxide ions in bases interact with the hydrocolloids in seaweeds (agarophytes and carrageenophytes) to form gels, which are too viscous to ferment [3]. This presents a challenge to the use of alkaline hydrolysis especially for red seaweeds. This can, however, be mitigated using the biorefinery approach, in which the hydrocolloids are extracted before diluted alkaline hydrolysis is applied to its residue. The biorefinery approach was used in a study which compared acid and base catalysts combined with enzymatic hydrolysis on carrageenan extraction residue of E. cottonii [57]. Glucose yields of $91 \%$ and $80 \%$ DM were obtained by treatment with $1 \% \mathrm{H}_{2} \mathrm{SO}_{4}$ and $1 \% \mathrm{NaOH}$, respectively [68]. Even though the glucose yield is higher for the acid treatment, the effect of inhibitors such as 5-HMF produced as a by-product of acid treatment on subsequent fermentation was not reported.

Dilute alkaline hydrolysis also yields degradation products or fermentation inhibitors in the form of 2-hydroxy-3-methyl-2-cyclopenten-1-one, 2,5-dimethyl-4-hydroxy-3(2H)-furanone and hydroxyacetone. The effect of these degradation products on fermentation processes is however unknown. It may present a significant advantage over dilute acid hydrolysis if found to be less adverse. Karray et al. [60] reported reducing sugar yields from base hydrolysis of $79 \% w / w$ total carbohydrates from Ulva rigida. It was noted in this study that inhibitors from base catalysed hydrolysis are only produced at very high concentrations of the catalyst. Hydrolysates from base catalysts also require 
neutralization as done with acid catalysts prior to fermentation [68]. This is to provide a suitable $\mathrm{pH}$ for organisms such as yeasts to ferment reducing sugars to ethanol.

Currently, no significant advantage has been identified from the use of base catalysts over acid catalysts in the hydrolysis of seaweed. A techno-economic analysis may be required to determine the extent to which either base or acid catalysts may be advantageous.

\subsection{Enzymatic Hydrolysis}

Enzymatic hydrolysis is considered the most effective in converting complex polysaccharides into simple sugars with a higher conversion efficiency and less toxic by-product formation [68]. The commonest enzymes used in the saccharification (hydrolysis) of seaweed are cellulases $[14,16,50,69,70]$. Cellulases is naturally secreted by cellulolytic bacterial species of Clostridium, Cellulomonas, Thermonospora, Bacillus, Bacteriodes, Ruminococcus, Erwinia, Acetovibrio, Microbispora and Streptomyces. They are also secreted by fungal species of Trichoderma, Penicillium, Fusarium, Phanerochaete, Humicola and Schizophillum [18].

Cellulases have been identified to be of three main types, namely endoglucanases, exoglucanases and $\beta$-glucosidases [18]. Each type performs a unique action on biomass during hydrolysis. Endoglucanase (endo 1,4-D-glucanhydrolase or E.C. 3.2.1.4) randomly incise internal amorphous sites in the cellulose polysaccharide chain generating oligosaccharides through a substitution reaction with a water molecule in the $1,4-\beta$ bond. The substitution reaction on internal linkages of the amorphous regions of cellulose fibres leads to formation of new reducing and non-reducing ends, which are vulnerable to further hydrolytic activity [71]. Exoglucanase (1,4- $\beta$-D-glucan cellobiohydrolase or E.C. 3.2.1.91) catalyse the residual reducing and non-reducing ends of the cellulose structure resulting from the endoglucanases activity. Its catalytic reaction with the free chain ends leads to the formation of cellobiose units. This reaction constitutes $40-70 \%$ of the total cellulase catalysis on cellulose [71]. $\beta$-Glucosidase (E.C. 3.2.1.21) hydrolyses soluble cellobiose and other cellodextrins in the aqueous phase to release glucose (hexose) units as final products [72].

Enzymes that are pentose-specific include complex mixtures of endo- $1,4-\beta-D-x y l a n a s e s$, exo-1,4- $\beta$-D-xylocuronidases, $\alpha$-L-arabinofuranosidases, endo-1,4- $\beta$-D-mannanases, $\beta$-mannosidases, acetyl xylan esterases, $\alpha$-glucoronidases and $\alpha$-galactosidases [73]. These hydrolyse polysaccharides in biomass to release not only pentoses but also hexoses. Enzyme mixtures are preferred for seaweed biomass hydrolysis in particular, since seaweeds are made up of various polysaccharides other than cellulose such as laminarin, mannitol, alginate, agar, carrageenan and ulvan [30]. Cellulases can also significantly hydrolyse these complex sugars especially when combined with other methods such as acid and hot water treatment [59,69]. Since glucan from brown seaweed contains $\alpha-(1,3), \alpha-(1,3)-(1,4)$ and $\alpha-(1,3)-(1.2)$ glycosidic linkages, amylases have also proved very efficient in releasing seaweed reducing sugars [74,75]. A reducing sugar concentration of $19.3 \mathrm{~g} / \mathrm{L}$ was obtained when amylase was used in hydrolysing salted Undaria pinnatifida [75].

The use of enzymes in hydrolysis offers enormous advantages in high reducing sugar yields in comparison to other methods. Enzymes are however $\mathrm{pH}$ sensitive (ideal $\mathrm{pH}$ range for cellulases: 4-6) and may require the use of buffers or $\mathrm{pH}$ adjustment with bases and acids to maximize their efficiency and maintain optimal enzyme activity. This creates an additional processing cost. The main disadvantages of the use of enzymes are its high production cost, long reaction time and difficulty in enzyme recovery. Costs associated with commercial enzymes, which remains a challenge for commercial bioethanol production from seaweed, could be minimized through development of seaweed-specific enzymes.

Studies in seaweed hydrolysis have primarily used cellulase enzyme mixtures such as Celluclast 1.5 L $[3,76]$ and Viscozyme L [10,69], which were originally developed for hydrolysis of lignocellulosic biomass. These enzyme cocktails mainly contain endo- and exoglucanases $[17,59]$. Some studies have used these enzyme brands alone [11] or in the form of enzyme mixtures to maximize reducing sugar yields [10,69]. In Kumar et al. [4], left-over pulp from the red seaweed, G. verrucosa was 
hydrolysed with a commercial cellulase from Trichoderma reesei (ATCC 26921) and $\beta$-glucosidase from Aspergillus niger (Novozyme 188). This yielded $0.87 \mathrm{~g}$ reducing sugars/g cellulose. This study is one of a few reported where enzymatic hydrolysis alone was used on seaweed. In most seaweed hydrolysis studies, enzymatic hydrolysis is combined with acid or thermal treatment [59]. This is because methods such as dilute acid treatment increases the reaction surface area of biomass for further action by enzymes when combined, maximizing the reducing sugar yield [50].

A study of such a case is by Borines et al. [14], where Sargassum sp. was acid treated with $4 \%$ $\mathrm{H}_{2} \mathrm{SO}_{4}$ at $115^{\circ} \mathrm{C}$ for $90 \mathrm{~min}$ followed by enzymatic hydrolysis with an enzyme loading of $50 \mathrm{FPU}$ cellulase $/ \mathrm{g}$ DM. The resulting reducing sugar concentration was $17.7 \mathrm{~g} / \mathrm{L}$ with a glucose concentration of $3.5 \mathrm{~g} / \mathrm{L}$. Typical enzyme dosages for cellulases applied to seaweeds have been between 10 to $150 \mathrm{FPU}$ cellulase/g DM [14].

In Kim et al. [3], an initial reducing sugar yield of $11.6 \%$ DM was obtained after acid treatment of $\mathrm{G}$. amansii with $0.1 \mathrm{~N} \mathrm{HCl}\left(121^{\circ} \mathrm{C}\right.$ for $\left.15 \mathrm{~min}\right)$. A final reducing sugar yield of $56.6 \% \mathrm{DM}$ was obtained after further hydrolysis with a mixture of Celluclast $1.5 \mathrm{~L}$ and Viscozyme L $(0.01 \mathrm{~g}$ enzyme $/ \mathrm{g}$ $\mathrm{DM}$ at $50{ }^{\circ} \mathrm{C}$ for $24 \mathrm{~h}$ ) [3]. An increase in reducing sugar yield of $79 \%$ was achieved from the combined treatments.

G. amansii $(10 \% w / v \mathrm{DM})$ was hydrolysed in another study, first with $94 \mathrm{mM} \mathrm{H}_{2} \mathrm{SO}_{4}\left(121{ }^{\circ} \mathrm{C}\right.$ for $60 \mathrm{~min}$ ) followed by enzymatic hydrolysis with a mixture of Celluclast $1.5 \mathrm{~L}$ and Viscozyme $\mathrm{L}$. This produced $43.5 \mathrm{~g} / \mathrm{L}$ of reducing sugars [64]. An overall sugar conversion efficiency of $57.4 \%$ of the total carbohydrate was achieved.

Abd-Rahim et al. [20], also combined acid and enzymatic hydrolysis. K. alvarezii ( $8 \% w / v \mathrm{DM})$ was first hydrolysed with $0.2 \mathrm{M} \mathrm{H}_{2} \mathrm{SO}_{4}\left(110^{\circ} \mathrm{C}\right.$ for $\left.90 \mathrm{~min}\right)$ to obtain an initial reducing sugar concentration of $34.3 \mathrm{~g} / \mathrm{L}$. This was followed by enzymatic hydrolysis with Celluclast at $50{ }^{\circ} \mathrm{C}$ for $48 \mathrm{~h}(1: 1$ enzyme to substrate ratio, $\mathrm{pH} 5.5$ ) to obtain a final reducing sugar concentration of $49.9 \mathrm{~g} / \mathrm{L}$ [20].

These studies emphasize a significant effect in the change in sugar yields when multiple hydrolysis treatments are used. The treatments are therefore not only competing but are also complementing each other in efficiency. The combined effect of dilute acid and enzymatic hydrolysis is remarkable but questions remain on the sustainable use of both technologies essentially due to enzyme costs and inhibitor formation. Table 4 shows a summary of studies conducted using acid and enzyme catalysts under various conditions. The reducing sugar yields shown in Table 4 are between 100 and $700 \mathrm{mg} / \mathrm{g}$ $\mathrm{DM}$, which is a positive indicator of the commercial value of ethanol production from seaweed.

Table 4. Summary of dilute acid and enzymatic hydrolysis conditions and their sugar yield.

\begin{tabular}{|c|c|c|c|c|c|c|c|c|c|c|c|}
\hline \multirow{2}{*}{$\begin{array}{l}\text { Seaweed Species } \\
\text { (Type of Seaweed) }\end{array}$} & \multirow{2}{*}{$\begin{array}{c}\mathrm{DM} \\
\% w / v\end{array}$} & \multicolumn{3}{|c|}{$\begin{array}{c}\text { Dilute Acid }\left(\mathrm{H}_{2} \mathrm{SO}_{4}\right) \\
\text { Treatment }\end{array}$} & \multicolumn{3}{|c|}{ Enzymatic Treatment } & \multicolumn{3}{|c|}{$\begin{array}{l}\text { Sugar Released } \\
(\mathrm{mg} / \mathrm{g} \text { DM })^{1}\end{array}$} & \multirow{2}{*}{ Ref. } \\
\hline & & $\begin{array}{l}\text { Conc. } \\
\text { (M) }\end{array}$ & $\begin{array}{l}\text { Temp. } \\
\left({ }^{\circ} \mathrm{C}\right)\end{array}$ & $\begin{array}{l}\text { Time } \\
\text { (min) }\end{array}$ & $\begin{array}{c}\text { Cellulase } \\
\text { (FPU/g DM) }\end{array}$ & $\begin{array}{c}\text { Time } \\
\text { (h) }\end{array}$ & $\begin{array}{l}\text { Temp. } \\
\left({ }^{\circ} \mathrm{C}\right)\end{array}$ & RSu & Glu & Gal & \\
\hline $\begin{array}{l}\text { U. fasciata } \\
\text { (green) }\end{array}$ & 5 & 0.1 & 100 & 60 & $\begin{array}{c}20 \\
\text { (mg protein) }\end{array}$ & 36 & 45 & 114 & & & [15] \\
\hline $\begin{array}{l}\text { Gelidium latifolium } \\
\text { (red) }\end{array}$ & 12 & 0.2 & 130 & 15 & & & & & 20 & 290 & [63] \\
\hline $\begin{array}{l}\text { Gracilaria sp. } \\
\text { (red) }\end{array}$ & 20 & 0.05 & 121 & 60 & $\begin{array}{c}10 \\
\text { (mg protein) }\end{array}$ & 6 & 50 & & 315 & 277 & [69] \\
\hline $\begin{array}{l}\text { K. alvarezii } \\
\text { (red) }\end{array}$ & 8 & 0.2 & 110 & 90 & 150 & 48 & 50 & 624 & & & [20] \\
\hline $\begin{array}{l}\text { Palmaria palmate } \\
\text { (red) }\end{array}$ & 10 & 0.2 & 121 & 15 & & & & 164 & & & [67] \\
\hline $\begin{array}{l}\text { Gracilaria verrucosa } \\
\text { (agar extraction, red) }\end{array}$ & 10 & & none & & 20 & 36 & 50 & 390 & & & {$[4]$} \\
\hline $\begin{array}{c}\text { L. japonica (brown) } \\
\text { (residue alginate } \\
\text { extractr.) }\end{array}$ & 10 & 0.01 & 121 & 60 & 45 & 48 & 50 & 278 & & & [50] \\
\hline $\begin{array}{l}\text { U. pinnatifida } \\
\text { (brown) }\end{array}$ & 13 & 0.075 & 121 & 60 & $\begin{array}{c}2.88 \\
(\mathrm{knu} / \mathrm{mL})\end{array}$ & 24 & 45 & 255 & & & [52] \\
\hline
\end{tabular}




\subsection{Other Methods of Hydrolysis}

There are several unconventional methods, which have also been applied in the pre-treatment and hydrolysis of seaweeds. These include HTT, ultrasound treatment, hot water wash and ball milling. They are often used as alternatives to mitigate the various concerns associated with the conventional chemical and enzymatic methods or in combination with them to maximize the reducing sugar yield.

Autoclave (thermal) treatment was used by Kim et al. [47]. It involved the autoclaving of G. amansii species at $121^{\circ} \mathrm{C}$ for time intervals of 20 to $80 \mathrm{~min}$ followed by enzymatic hydrolysis with cellulase ( $8.0 \mathrm{mg} / \mathrm{g}$ biomass) and $\beta$-glucosidase $(4.0 \mathrm{mg} / \mathrm{g}$ biomass). The resulting total reducing sugar yields between the raw and autoclave treated biomass were similar at 0.53 and $0.58 \mathrm{~g} / \mathrm{g}$ biomass, respectively. The glucose yield was however, highest with autoclave treatment at $0.45 \mathrm{~g} / \mathrm{g}$ biomass compared to $0.20 \mathrm{~g} / \mathrm{g}$ biomass for the untreated [47]. This suggests that autoclave treatment is an efficient means to reduce the galactan release and increase the relative content of glucose when used in combination with enzymatic hydrolysis.

Yoon et al. [77] assessed the effect of gamma irradiation on saccharification of Undaria sp. for bioethanol production. Irradiation has been used for pre-treatment of lignocellulosic biomass such as bagasse and wheat straw to hydrolyse the polysaccharides in combination with dilute acid hydrolysis. Wet samples of Undaria sp. were irradiated at $22^{\circ} \mathrm{C}$ at a dose rate of $10 \mathrm{kGy} / \mathrm{h}$ reaching dose levels between 10 and $500 \mathrm{kGy}$. The concentration of reducing sugars increased with increasing levels of gamma irradiation. At zero irradiation the reducing sugar concentration was $0.017 \mathrm{~g} / \mathrm{L}$, whereas at a dose of $500 \mathrm{kGy}$ the concentration increased to $0.048 \mathrm{~g} / \mathrm{L}$ [77]. This suggests that gamma irradiation combines with dilute acid hydrolysis effectively to maximize reducing the sugar release.

In a study by Gao et al. [59], integrated hydroxyl radicals and hot water pre-treatment (IHRHW) was used in combination with enzymatic hydrolysis to hydrolyse Macrocystis pyrifera. The hydroxyl radicals (HR) generated by Fenton or Haber-Weiss reaction in vivo is a very reactive free radical, which can break the hydrogen bonds in carbohydrates and lignin to release simple sugars [59]. IHRHW treatment was conducted in a two-step process, beginning with hot water pre-treatment followed by the Fenton reaction, before enzymatic hydrolysis. Glucose release was $24.1 \mathrm{~g} / \mathrm{g}$ DM for the untreated seaweed and $58.6 \mathrm{~g} / \mathrm{g}$ DM for the seaweed treated with IHRHW [59]. This suggests that the IHRHW is efficient in maximizing sugar recovery when combined with enzymatic hydrolysis.

In a study by Schultz-Jensen et al. [17], C. linum was subjected to HTT, wet oxidation (WO), steam explosion (STEX), plasma-assisted pre-treatment (PAP) and ball milling (BM), which are usually used in pre-treatment and hydrolysis of terrestrial biomass. WO (at $200{ }^{\circ} \mathrm{C}$ ) gave the highest glucan yield of $74 \mathrm{~g} / 100 \mathrm{~g}$ DM as compared to the untreated seaweed with $38 \mathrm{~g} / 100 \mathrm{~g} \mathrm{DM}$. HTT (at $200{ }^{\circ} \mathrm{C}$ ), STEX (at $210^{\circ} \mathrm{C}$ ), PAP (for $60 \mathrm{~min}$ ) and BM (for $18 \mathrm{~h}$ ) gave glucan yields of $64,50,38$ and $36 \mathrm{~g} / 100 \mathrm{~g} \mathrm{DM}$, respectively [17]. This suggests that WO and HTT methods of pre-treatment are also effective but concerns over the amount of energy expended in them would require further analysis. An EROI (Energy return on energy investment) analysis could be used to assess the sustainable application of these methods.

Karray et al. [60] comparatively evaluated the effect of acid catalysis, thermoalkaline, ultrasonication and enzymatic hydrolysis on the green algae, U. rigida. The ultrasound method is known to disrupt cells releasing intracellular contents with minimal toxicity, in a short extraction time and at moderate costs. Reducing sugar concentrations of 3.6, 2.9, 2.5 and 7.3 g/L were obtained for acid catalysis, thermoalkaline, ultrasonication and enzymatic hydrolysis, respectively [60]. Ultrasonication proved most inefficient as an alternative to the high yielding enzymatic and acid methods of hydrolysis.

To eliminate issues such as the use of toxic chemicals, long reaction times and high costs associated with the use of acids and enzymes during hydrolysis, hydrothermal conditions with subcritical water was used in a study on S. japonica [78]. Subcritical water refers to liquid water under pressure at temperatures between the boiling point $\left(100{ }^{\circ} \mathrm{C}\right)$ and the critical temperature $\left(374{ }^{\circ} \mathrm{C}\right)$ of water. This technique employs the use of hot water under high pressure to maintain the liquid state while changing the physical features such as solvent viscosity, surface tension and dielectric constant [64]. 
These features support in the depolymerization of the seaweed. A maximum glucose concentration of $0.43 \mathrm{~g} / \mathrm{L}$ was obtained at a temperature of $180^{\circ} \mathrm{C}$ and a pressure of $13 \mathrm{bar}$.

The results of the various studies described in this section shows that indeed efficient alternative treatments are available, mostly to enhance the efficiency of conventional acid and enzymatic hydrolysis treatments. An effective independent alternative which is less energy-consuming is still yet to be found.

\section{Seaweed Fermentation Techniques}

Fermentation is also a very critical stage of the entire bioethanol production process primarily because it is at this stage that ethanol is produced by an organism from the reducing sugars obtained after hydrolysis. It may not be the rate limiting stage of bioethanol production but its efficiency contributes enormously towards the final ethanol yield. The techniques or pathways used generally in the fermentation of seaweed are Separate Hydrolysis and Fermentation (SHF) and; Simultaneous Saccharification and Fermentation (SSF).

\subsection{Separate Hydrolysis and Fermentation (SHF)}

This process is the most commonly used mainly because of the flexibility it offers in the selection of the hydrolysis process. It also allows for the use of optimum conditions for both catalysts and fermenting organisms used for the hydrolysis and fermentation processes, respectively [47]. In SHF, the hydrolysis process is first completed and the reducing sugars recovered (optional step) mainly via centrifugation or filtration, before the introduction of an organism for fermentation. The two processes may or may not take place in the same reactor. SHF was applied in a study on G. tenuistipitata in which acid hydrolysis was used to obtain the reducing sugars followed by fermentation with Saccharomyces cerevisiae to obtain an ethanol yield of $0.042 \mathrm{~g} / \mathrm{g}$ reducing sugars [8]. The SHF approach was also used on U. pinnatifida with Pichia angophorae as the fermenting organism producing an ethanol yield of $0.33 \mathrm{~g} / \mathrm{g}$ reducing sugars [43]. Kumar et al. [4] also used SHF in a study where bioethanol was produced from the agar extraction pulp of G. verrucosa [4]. The enzymatic hydrolysis and fermentation of the pulp with $S$. cerevisiae produced an ethanol yield of $0.43 \mathrm{~g} / \mathrm{g}$ reducing sugars.

\subsection{Simultaneous Saccharification and Fermentation (SSF)}

In the SSF process, an enzyme for saccharification and a fermenting organism such as yeast are introduced into the reactor at the same time and under similar conditions of operation. The process tends to be cost-effective since both hydrolysis and fermentation are done in the same reactor at the same time but optimum conditions for the two processes are not always achieved [79]. This is because conditions for both saccharification (hydrolysis) and fermentation are not the same as seen in Tables 4 and 5. Typical enzymatic (cellulase) hydrolysis temperatures are at $45-55{ }^{\circ} \mathrm{C}$ whereas typical fermentation temperatures are at $28-40{ }^{\circ} \mathrm{C}$. The SSF process was used in bioethanol production from the brown algae, L. japonica [32]. The seaweed was first pre-treated with $0.06 \% \mathrm{H}_{2} \mathrm{SO}_{4}$ at $170{ }^{\circ} \mathrm{C}$ for $15 \mathrm{~min}$. SSF was conducted with cellulase as the enzyme and $\mathrm{S}$. cerevisiae as the fermenting organism at temperatures between $37-46^{\circ} \mathrm{C}$ for $48 \mathrm{~h}$ at $130 \mathrm{rpm}$. An ethanol concentration of $6.65 \mathrm{~g} / \mathrm{L}$ was obtained [32].

SSF is reported to be a higher yielding process than SHF. This hypothesis was confirmed in a study on G. amansii, where maximum ethanol concentrations of 3.78 and $3.33 \mathrm{~g} / \mathrm{L}$ were obtained for SSF and SHF, respectively with cellulase as the enzyme and S. cerevisiae (KCTC 7906) as the fermenting organism [47]. Conversion efficiencies of 84.9 and $74.7 \%$ were achieved for SSF and SHF, respectively. During the SHF process, the enzymatic hydrolysis was conducted at $37^{\circ} \mathrm{C}$ for $24 \mathrm{~h}$ and fermentation at $30{ }^{\circ} \mathrm{C}$ for $12 \mathrm{~h}$ while the entire SSF process was conducted at $37^{\circ} \mathrm{C}$ for $24 \mathrm{~h}$. These results recommend that not only is SSF more efficient than SHF but it also saves time. The biggest challenge in the use of SSF still rests on its limited application to bioethanol processes, which includes the use of enzyme 
catalysts. Table 5 shows the ethanol yield from various seaweed species. It shows the differences in SSF and SHF ethanol yield to be marginal and different for each seaweed species.

Table 5. Comparison of ethanol yield from various seaweeds.

\begin{tabular}{|c|c|c|c|c|c|c|c|c|c|}
\hline \multirow{2}{*}{$\begin{array}{l}\text { Seaweed } \\
\text { (Type of } \\
\text { Seaweed) }\end{array}$} & \multirow{2}{*}{$\begin{array}{c}\text { Mode of } \\
\text { Hydrolysis \& } \\
\text { Fermentation }^{1}\end{array}$} & \multicolumn{4}{|c|}{ Fermentation Conditions } & \multicolumn{3}{|c|}{ Ethanol Yield $^{2}$} & \multirow[b]{2}{*}{ Ref. } \\
\hline & & Organism & $\begin{array}{l}\text { Temp. } \\
\left({ }^{\circ} \mathrm{C}\right)\end{array}$ & $\mathrm{pH}$ & $\begin{array}{l}\text { Time } \\
\text { (h) }\end{array}$ & $\begin{array}{l}\text { Yield } \\
\text { (g/100 g) }\end{array}$ & $\begin{array}{l}\text { Yield } \\
\text { Basis }\end{array}$ & $\begin{array}{l}\text { Conversion } \\
\text { Efficiency } \\
(\% w / w)\end{array}$ & \\
\hline $\begin{array}{l}\text { U. fasciata } \\
\text { (green) }\end{array}$ & $\mathrm{EH}, \mathrm{SHF}$ & $\begin{array}{l}\text { S. cerevisiae } \\
\text { MTCC } 180\end{array}$ & 28 & & 12 & 47 & $\mathrm{RSu}$ & & [16] \\
\hline $\begin{array}{l}\text { U. fasciata } \\
\text { (green) }\end{array}$ & $\mathrm{EH}, \mathrm{SHF}$ & S. cerevisiae & 28 & & 48 & 47 & $\mathrm{RSu}$ & $88 \%$ & [15] \\
\hline $\begin{array}{l}\text { E. cottonii } \\
\text { (red) }\end{array}$ & $\mathrm{AH}, \mathrm{SHF}$ & S. cerevisiae & 34 & 6.5 & 144 & 33 & $\mathrm{RSu}$ & & [80] \\
\hline $\begin{array}{l}\text { Gracilaria sp. } \\
\text { (red) }\end{array}$ & $\mathrm{AH} \& \mathrm{EH}, \mathrm{SHF}$ & $\begin{array}{l}\text { S. cerevisiae } \\
\mathrm{Wu}\end{array}$ & 30 & 4.5 & 48 & 47 & $\mathrm{RSu}$ & $94 \%$ & [69] \\
\hline $\begin{array}{l}\text { G. amansii } \\
\text { (red) }\end{array}$ & $\mathrm{AH}, \mathrm{SHF}$ & $\begin{array}{l}\text { Brettanomyces } \\
\text { custersii }\end{array}$ & 30 & 7.0 & 39 & 38 & $\mathrm{RSu}$ & $74 \%$ & [12] \\
\hline $\begin{array}{l}\text { G. verrucose } \\
\text { (red) }\end{array}$ & $\mathrm{AH}, \mathrm{SHF}$ & $\begin{array}{l}\text { S. cerevisiae } \\
\text { HAU }\end{array}$ & 30 & 6.5 & 36 & 43 & $\mathrm{RSu}$ & $84 \%$ & [4] \\
\hline $\begin{array}{l}\text { K. alvarezii } \\
\text { (red) }\end{array}$ & $\mathrm{AH}, \mathrm{SHF}$ & $\begin{array}{l}\text { S. cerevisiae } \\
\text { NCIM }\end{array}$ & 30 & 6.6 & 48 & 53 & RSu & $103 \%$ & [62] \\
\hline $\begin{array}{l}\text { K. alvarezii } \\
\text { (red) }\end{array}$ & $\mathrm{AH}, \mathrm{SSF}$ & Brewer's yeast & 30 & 5.0 & 72 & 21 & Gal & $41 \%$ & [80] \\
\hline $\begin{array}{l}\text { L. japonica } \\
\text { (brown) }\end{array}$ & $\mathrm{AH} \& \mathrm{EH}, \mathrm{SHF}$ & $\begin{array}{l}\text { Escherichia coli } \\
\text { KO11 }\end{array}$ & 30 & 5.5 & 24 & 41 & RSu & $78 \%$ & {$[3]$} \\
\hline $\begin{array}{l}\begin{array}{l}\text { L. japonica } \\
\text { (brown) }\end{array} \\
\end{array}$ & $\mathrm{AH} \& \mathrm{EH}, \mathrm{SHF}$ & S. cerevisiae & 30 & 6.5 & 36 & 44 & Glu & & [50] \\
\hline $\begin{array}{l}\text { Sargassum sp. } \\
\text { (brown) }\end{array}$ & $\mathrm{AH} \& \mathrm{EH}, \mathrm{SHF}$ & S. cerevisiae & 40 & 4.5 & 36 & 17 & RSu & $33 \%$ & [14] \\
\hline $\begin{array}{l}\text { K. alvarezii } \\
\text { (red) }\end{array}$ & $\mathrm{TH}, \mathrm{SSF}$ & S. cerevisiae & $37-46$ & 4.8 & 9 & 51 & Glu & $91 \%$ & [57] \\
\hline $\begin{array}{l}\text { S. japonica } \\
\text { (green) }\end{array}$ & $\mathrm{AH}, \mathrm{SSF}$ & S. cerevisiae & $37-46$ & 4.8 & 48 & 34 & Glu & $67 \%$ & [32] \\
\hline $\begin{array}{l}\text { C. linum } \\
\text { (green) }\end{array}$ & WO \& EH, SSF & S. cerevisiae & 32 & 4.8 & 200 & 44 & Glu & $77 \%$ & [17] \\
\hline $\begin{array}{l}\text { Sargassum } \\
\text { sagamianum } \\
\text { (brown) }\end{array}$ & TH \& EH, SHF & $\begin{array}{l}\text { P. stipitis } \\
\text { CBS7126 }\end{array}$ & 30 & 7.0 & & 44 & $\mathrm{RSu}$ & & [13] \\
\hline
\end{tabular}

${ }^{1}$ EH: Enzymatic hydrolysis, AH: Acid hydrolysis, WO: Wet oxidation, TH: Thermal hydrolysis. ${ }^{2}$ RSu: Reducing sugar, Glu: Glucose, Gal: Galactose.

\subsection{Other Fermentation Methods}

Apart from the SSF and SHF processes, other less common alternative pathways include Simultaneous Saccharification and Co-fermentation (SSCF) and, Consolidated Bioprocessing (CBP). CBP processes take place simultaneously in a single reactor combining the production of cellulose, hydrolysis of the biomass and the fermentation of hydrolysates to ethanol [81]. In these processes, single or combined consortia of microorganisms are used, reducing capital costs. Organisms capable of CBP include Clostridium thermocellum, Neurospora crassa, Fusarium oxysporum and Paecilomyces sp. [18].

The SSCF process often involves the concurrent fermentation of two or more substrates with one or more inoculum in a single system. It may also involve the concurrent fermentation of sugars found in different process streams [82]. SSCF yielded $64.3 \mathrm{~g} / \mathrm{L}$ ethanol with K. alvarezii as feedstock, separated into a galactose rich liquid fraction and a cellulose rich solid fraction [11]. Comparatively, SSF was used in the same study to separately ferment the liquid and solid fraction to obtain ethanol yields of 38 and $53 \mathrm{~g} / \mathrm{L}$, respectively [11]. The results indicate that even though SSCF is a useful method, separately applying SSF will result in a much higher combined ethanol yield from different fractions of the same biomass. Some co-fermenting micro-organisms for SSCF include strains of S. cerevisiae, E. coli, Z mobilis, P. tannophilus, C. shehatae and P. stipitis [79]. 


\subsection{Organisms Used in Fermentation}

Various organisms have been used to ferment reducing sugars to ethanol. These are mainly fungal and bacterial species. Some of these species that have been used in fermenting sugars from seaweed include S. cerevisiae [17,55,57], P. angophorae [43,48,83], P. stipitis [17,50,84] and Escherichia coli [85]. S. cerevisiae is the commonest organism used in fermenting reducing sugars from various types of biomass due to its low cost and availability. Various strains are available but the commonest strains are the baker's and brewer's yeast, which are available for purchase on the open market. S. cerevisiae is known to be selective towards hexose reducing sugars such as the glucose, galactose and mannose fraction of hydrolysates during fermentation, leaving pentose reducing sugars such as xylose and arabinose [86]. A pentose fermenting organism that has been identified and used is the P. stipitis [87]. In a study where $P$. stipitis was used, ethanol yields of $0.08,0.07$ and $0.05 \mathrm{~g} / \mathrm{g}$ reducing sugars were obtained from hydrolysates of Ulva sp., Gracilaria sp. and Costaria costata, respectively [87].

A study also identified the yeast strain, P. angophorae (CBS 5830) as having the capacity to ferment the sugar alcohol, mannitol while producing the enzyme laminarinase which hydrolyses laminarin [41]. Laminarin and mannitol are sugars mainly found in brown seaweeds. An ethanol concentration of $5.1 \mathrm{~g} / \mathrm{L}$ was obtained at a conversion efficiency of $73 \%$ when $P$. angophorae was used in fermenting the brown seaweed, S. latissima [41]. Ota et al. [85] also compared the performance of three different yeast strains, Saccharomyces paradoxus, P. angophorae and E. coli when fed with mannitol and glucose as substrates. The ethanol concentration when mannitol was used as substrate was 8.9, 9.3 and 9.2 g/L for S. paradoxus, P. angophorae and E. coli, respectively while ethanol concentration with glucose as substrate was 10.2, 11.5 and $11.0 \mathrm{~g} / \mathrm{L}$ for the respective microorganisms [85]. These results suggest that the three organisms selected in the study would all be ideal fermenting organisms for brown seaweed due to their efficient glucose and mannitol to ethanol conversion.

The acclimation of yeasts to greater concentrations of a particular substrate has been considered as a method to improve ethanol yield. This was done in a study within which a two-stage fermentation technique was used on hydrolysates from S. japonica [76]. In the first stage fermentation, S. cerevisiae KCCM 1129 was used, targeting the conversion of glucose to ethanol and; in the second stage fermentation, P. angophorae KCTC 17574 was used targeting the conversion of mannitol to ethanol. Non-acclimated P. angophorae produced $0.13 \mathrm{~g}$ ethanol $/ \mathrm{g}$ mannitol whereas $P$. angophorae acclimated with $50 \mathrm{~g} / \mathrm{L}$ mannitol for $24 \mathrm{~h}$ during its culturing, produced $0.30 \mathrm{~g}$ ethanol/g mannitol [76]. Based on this successful acclimation, it would be interesting to know the effect of various yeast strains on ethanol yield when acclimated to pentoses such as xylose and arabinose, which is currently not in literature. The biggest challenge in seaweed hydrolysate fermentation still remains, the identification of an organism capable of converting the heterogeneous sugars (hexoses, pentoses and sugar alcohols) found in them [88].

\section{Bioethanol Recovery Processes}

The most extensive use of bioethanol is as fuel for engines and as fuel additive. It is refined after fermentation through distillation and dehydration processes [2]. Distillation is the main process used in the recovery of ethanol from the fermentation broth (mixture of ethanol, solid biomass residue, residual sugars, enzymes (if applied) and fermenting organisms). It stands out as the most energy intensive stage in the entire ethanol production process primarily due to the heat generated for vaporizing ethanol-water mixtures [89]. Bioethanol can be recovered with simple distillation units and rotary evaporators for analytical and litre scale research work while larger units such as distillation columns are used for commercial processes [90]. Commercial processes employ a combination of distillation columns and an ethanol dewatering technique such as the use of molecular sieves to recover ethanol beyond the ethanol-water azeotrope [91]. Distillation columns can distil fermentation broths to $95.6 \%$ ethanol concentration (ethanol-water azeotrope) after which dehydration processes such as vacuum distillation, pressure swing, membranes or molecular sieves are used to obtain $>99 \%$ grade ethanol [2]. Molecular sieves exploit the difference in the size of water and ethanol molecules to selectively adsorb 
water. They are more advantageous for dehydration because they can be regenerated continuously for reuse through drying. Zeolite is an example of a molecular sieve material.

\section{Conclusions and Perspectives}

Research on bioethanol production from seaweed has been elucidated as a very promising technology. Indeed, its hydrolysis and fermentation processes still have challenges, which needs to be resolved but its prospects remain greater in comparison with land-based crops and agricultural residues. The selection of the hydrolysis process for seaweed bioethanol is still limited to the conventional acid and enzymatic hydrolysis methods. These conventional methods however, complement each other to efficiently hydrolyse seaweeds. Alternatives that are less energy intensive, cost-effective and non-toxic are still required to effectively complement or replace them. The sustainable combination of the different hydrolysis processes is a major concern.

The fermentation stage was limited in efficiency, mainly, by the identification of fermenting organisms capable of converting hexoses, pentoses and sugar alcohols from seaweeds to ethanol and not, the selection between SHF and SSF pathways. Marginal differences in seaweed ethanol yields between SHF and SSF are currently reported.

The utilization of only the carbohydrate fraction during hydrolysis and fermentation processes from the entire seaweed biomass results in the generation of large amounts of organic wastes (proteins, lipids, unhydrolyzed polysaccharides, unfermented monosaccharides) especially on the commercial scale. The economic value of seaweeds for bioethanol production could be maximized using the biorefinery approach to biomass processing. In this approach, apart from bioethanol production, several organic and inorganic fractions of seaweeds can be harnessed through, hydrocolloids extraction, anaerobic digestion, substrate oxidation to bioelectricity and agricultural applications (soil amendment and animal feed preparation).

Author Contributions: Contributions from the authors include: conceptualization, F.O.; writing-original draft preparation, F.O. and A.T.; writing-review and editing, M.M., F.K., A.T. and F.O.

Funding: This research was funded by DANIDA Fellowship Centre (Denmark's development cooperation) grant number [14-01DTU] through the research project, Seaweed Biorefinery in Ghana (SeaBioGha).

Acknowledgments: The authors are grateful to DANIDA for their support and to all collaborators at the Technical University of Denmark, Kwame Nkrumah University of Science and Technology, Ghana, and the Water Research Institute (WRI), Council for Scientific and Industrial Research (CSIR), Ghana involved in the SeaBioGha project.

Conflicts of Interest: The authors declare no conflict of interest.

\section{References}

1. REN21. Advancing the Global Renewable Energy Transition. Renewables 2018 Global Status Report 2018 in Perspective. 2018. Available online: http:/ / www.ren21.net/wp-content/uploads/2018/06/GSR_2018_ Highlights_final.pdf (accessed on 9 November 2018).

2. Baeyens, J.; Kang, Q.; Appels, L.; Dewil, R.; Lv, Y.; Tan, T. Challenges and opportunities in improving the production of bio-ethanol. Prog. Energy Combust. Sci. 2015, 47, 60-88. [CrossRef]

3. Kim, N.J.; Li, H.; Jung, K.; Chang, H.N.; Lee, P.C. Ethanol production from marine algal hydrolysates using Escherichia coli KO11. Bioresour. Technol. 2011, 102, 7466-7469. [CrossRef] [PubMed]

4. Kumar, S.; Gupta, R.; Kumar, G.; Sahoo, D.; Kuhad, R.C. Bioethanol production from Gracilaria verrucosa, a red alga, in a biorefinery approach. Bioresour. Technol. 2013, 135, 150-156. [CrossRef] [PubMed]

5. Kostas, E.T.; White, D.; Du, C.; Cook, D.J. Selection of yeast strains for bioethanol production from UK seaweeds. J. Appl. Phycol. 2015, 1427-1441. [CrossRef] [PubMed]

6. Jones, C.S.; Mayfield, S.P. Algae biofuels: Versatility for the future of bioenergy. Curr. Opin. Biotechnol. 2012, 23, 346-351. [CrossRef] [PubMed]

7. Taherzadeh, M.J.; Karimi, K. Pretreatment of lignocellulosic wastes to improve ethanol and biogas production: A review. Int. J. Mol. Sci. 2008, 9, 1621-1651. [CrossRef] [PubMed] 
8. Chirapart, A.; Praiboon, J.; Puangsombat, P.; Pattanapon, C.; Nunraksa, N. Chemical composition and ethanol production potential of Thai seaweed species. J. Appl. Phycol. 2014, 26, 979-986. [CrossRef]

9. Xu, X.; Kim, J.Y.; Oh, Y.R.; Park, J.M. Production of biodiesel from carbon sources of macroalgae, Laminaria japonica. Bioresour. Technol. 2014, 169, 455-461. [CrossRef] [PubMed]

10. Hong, I.K.; Jeon, H.; Lee, S.B. Comparison of red, brown and green seaweeds on enzymatic saccharification process. J. Ind. Eng. Chem. 2014, 20, 2687-2691. [CrossRef]

11. Hargreaves, P.I.; Barcelos, C.A.; da Costa, A.C.A.; Pereira, N. Production of ethanol $3 G$ from Kappaphycus alvarezii: Evaluation of different process strategies. Bioresour. Technol. 2013, 134, 257-263. [CrossRef] [PubMed]

12. Park, J.H.; Hong, J.Y.; Jang, H.C.; Oh, S.G.; Kim, S.H.; Yoon, J.J.; Kim, Y.J. Use of Gelidium amansii as a promising resource for bioethanol: A practical approach for continuous dilute-acid hydrolysis and fermentation. Bioresour. Technol. 2012, 108, 83-88. [CrossRef] [PubMed]

13. Lee, S.M.; Lee, J.H. Ethanol fermentation for main sugar components of brown-algae using various yeasts. J. Ind. Eng. Chem. 2012, 18, 16-18. [CrossRef]

14. Borines, M.G.; de Leon, R.L.; Cuello, J.L. Bioethanol production from the macroalgae Sargassum spp. Bioresour. Technol. 2013, 138, 22-29. [CrossRef] [PubMed]

15. Trivedi, N.; Gupta, V.; Reddy, C.R.K.; Jha, B. Enzymatic hydrolysis and production of bioethanol from common macrophytic green alga Ulva fasciata Delile. Bioresour. Technol. 2013, 150, 106-112. [CrossRef] [PubMed]

16. Trivedi, N.; Reddy, C.R.K.; Radulovich, R.; Jha, B. Solid state fermentation (SSF)-derived cellulase for saccharification of the green seaweed Ulva for bioethanol production. Algal Res. 2015, 9, 48-54. [CrossRef]

17. Schultz-Jensen, N.; Thygesen, A.; Leipold, F.; Thomsen, S.T.; Roslander, C.; Lilholt, H.; Bjerre, A.B. Pretreatment of the macroalgae Chaetomorpha linum for the production of bioethanol-Comparison of five pretreatment technologies. Bioresour. Technol. 2013, 140, 36-42. [CrossRef] [PubMed]

18. Gupta, A.; Prakash, J. Sustainable bio-ethanol production from agro-residues: A review. Renew. Sustain. Energy Rev. 2015, 41, 550-567. [CrossRef]

19. Borines, M.G.; McHenry, M.P.; de Leon, R.L. Integrated macroalgae production for sustainable bioethanol, aquaculture and agriculture in Pacific island nations. Biofuels Bioprod. Biorefining 2011, 5, 599-608. [CrossRef]

20. Abd-Rahim, F.; Wasoh, H.; Zakaria, M.R.; Ariff, A.; Kapri, R.; Ramli, N.; Siew-Ling, L. Production of high yield sugars from Kappaphycus alvarezii using combined methods of chemical and enzymatic hydrolysis. Food Hydrocoll. 2014, 42, 309-315. [CrossRef]

21. Matanjun, P.; Mohamed, S.; Mustapha, N.M.; Muhammad, K. Nutrient content of tropical edible seaweeds, Eucheuma cottonii, Caulerpa lentillifera and Sargassum polycystum. J. Appl. Phycol. 2009, 21, 75-80. [CrossRef]

22. Ben Yahmed, N.; Imel, M.A.; Ben Alaya, M.; Bouallagui, H.; Marzouki, M.N.; Smaali, I. A biorefinery concept using the green macroalgae Chaetomorpha linum for the coproduction of bioethanol and biogas. Energy Convers. Manag. 2016, 119, 257-265. [CrossRef]

23. Lee, S.Y.; Chang, J.H.; Lee, S.B. Chemical composition, saccharification yield, and the potential of the green seaweed Ulva pertusa. Biotechnol. Bioprocess. Eng. 2014, 19, 1022-1033. [CrossRef]

24. El Harchi, M.; Fakihi Kachkach, F.Z.; El Mtili, N. Optimization of thermal acid hydrolysis for bioethanol production from Ulva rigida with yeast Pachysolen tannophilus. S. Afr. J. Bot. 2018, 115, 161-169. [CrossRef]

25. Do, J.R.; Nam, Y.J.; Park, J.H.; Jo, J.H. Studies on chemical composition of red algae. J. Kor. Fish Soc. 1997, 30, 428-431.

26. Rhein-Knudsen, N.; Ale, M.T.; Ajalloueian, F.; LiYun, Y.; Meyer, A.S. Rheological properties of agar and carrageenan from Ghanaian red seaweeds. Food Hydrocoll. 2017, 63, 50-58. [CrossRef]

27. Fayaz, M.; Namitha, K.K.; Murthy, K.N.C.; Swamy, M.M.; Sarada, R.; Khanam, S.; Subbarao, P.V.; Ravishankar, G.A. Chemical composition, iron bioavailability, and antioxidant activity of Kappaphycus alvarezzi (Doty). J. Agric. Food Chem. 2005, 53, 792-797. [CrossRef] [PubMed]

28. Wong, K.H.; Cheung, P.C.K. Nutritional evaluation of some subtropical red and green seaweeds Part I-Proximate composition, amino acid profiles and some physico-chemical properties. Food Chem. 2000, 71, 475-482. [CrossRef]

29. Manns, D.; Deutschle, A.L.; Saake, B.; Meyer, A.S. Methodology for quantitative determination of the carbohydrate composition of brown seaweeds (Laminariaceae). RSC Adv. 2014, 4, 25736-25746. [CrossRef] 
30. Chen, H.; Zhou, D.; Luo, G.; Zhang, S.; Chen, J. Macroalgae for biofuels production: Progress and perspectives. Renew. Sustain. Energy. Rev. 2015, 47, 427-437. [CrossRef]

31. Trivedi, N.; Baghel, R.S.; Bothwell, J.; Gupta, V.; Reddy, C.R.K.; Lali, A.M.; Jha, B. An integrated process for the extraction of fuel and chemicals from marine macroalgal biomass. Sci. Rep. 2016, 6, 1-8. [CrossRef] [PubMed]

32. Ye Lee, J.; Li, P.; Lee, J.; Ryu, H.J.; Oh, K.K. Ethanol production from Saccharina japonica using an optimized extremely low acid pretreatment followed by simultaneous saccharification and fermentation. Bioresour. Technol. 2013, 127, 119-125. [CrossRef] [PubMed]

33. Thygesen, A.; Oddershede, J.; Lilholt, H.; Thomsen, A.B.; Ståhl, K. On the determination of crystallinity and cellulose content in plant fibres. Cellulose 2005, 12, 563. [CrossRef]

34. Lahaye, M.; Robic, A. Structure and functional properties of Ulvan, a polysaccharide from green seaweeds. Biomacromolecules 2007, 8, 24-30. [CrossRef] [PubMed]

35. Manns, D.; Andersen, S.K.; Saake, B.; Meyer, A.S. Brown seaweed processing: Enzymatic saccharification of Laminaria digitata requires no pre-treatment. J. Appl. Pshchol. 2016, 28, 1287-1294. [CrossRef]

36. Rhein-Knudsen, N.; Ale, M.T.; Ajalloueian, F.; Meyer, A.S. Characterization of alginates from Ghanaian brown seaweeds: Sargassum spp. and Padina spp. Food Hydrocoll. 2017, 71, 236-244. [CrossRef]

37. Tajima, T.; Tomita, K.; Miyahara, H.; Watanabe, K.; Aki, T.; Okamura, Y.; Matsumura, Y.; Nakashimada, Y.; Kato, J. Efficient conversion of mannitol derived from brown seaweed to fructose for fermentation with a thraustochytrid. J. Biosci. Bioeng. 2018, 125, 180-184. [CrossRef] [PubMed]

38. Rhein-Knudsen, N.; Ale, M.T.; Meyer, A.S. Seaweed hydrocolloid production: An update on enzyme assisted extraction and modification technologies. Mar. Drugs 2015, 13, 3340-3359. [CrossRef] [PubMed]

39. McHugh, D.J. A Guide to the Seaweed Industry FAO Fisheries Technical Paper 441; Food and Agricultural Organization: Rome, Italy, 2003.

40. Bohutskyi, P.; Bouwer, E. Biogas production from algae and cyanobacteria through anaerobic digestion: A review, analysis, and research needs. In Advanced Biofuels and Bioproducts; Springer: New York, NY, USA, 2013; pp. 873-975.

41. Adams, J.M.M.; Toop, T.A.; Donnison, I.S.; Gallagher, J.A. Seasonal variation in Laminaria digitata and its impact on biochemical conversion routes to biofuels. Bioresour. Technol. 2011, 102, 9976-9984. [CrossRef] [PubMed]

42. Masarin, F.; Cedeno, F.R.P.; Chavez, E.G.S.; Oliveira, L.E.; Gelli, V.C.; Monti, R. Chemical analysis and biorefinery of red algae Kappaphycus alvarezii for efficient production of glucose from residue of carrageenan extraction process. Biotechnol. Biofuels 2016, 9, 122. [CrossRef] [PubMed]

43. Cho, Y.; Kim, H.; Kim, S.K. Bioethanol production from brown seaweed, Undaria pinnatifida, using $\mathrm{NaCl}$ acclimated yeast. Bioprocess Biosyst. Eng. 2013, 36, 713-719. [CrossRef] [PubMed]

44. Enquist-Newman, M.; Faust, A.M.E.; Bravo, D.D.; Santos, C.N.S.; Raisner, R.M.; Hanel, A.; Sarvabhowman, P.; Le, C.; Regitsky, D.D.; Cooper, S.R.; et al. Efficient ethanol production from brown macroalgae sugars by a synthetic yeast platform. Nature 2014, 505, 239. [CrossRef] [PubMed]

45. Ale, M.T.; Meyer, A.S. Fucoidans from brown seaweeds: An update on structures, extraction techniques and use of enzymes as tools for structural elucidation. RSC Adv. 2013, 3, 8131-8141. [CrossRef]

46. Horn, S.J. Seaweed Biofuels: Production of Biogas and Bioethanol from Brown Macroalgae; VDM, Verlag Dr. Müller: Saarbrucken, Germany, 2009.

47. Kim, H.M.; Wi, S.G.; Jung, S.; Song, Y.; Bae, H.J. Efficient approach for bioethanol production from red seaweed Gelidium amansii. Bioresour. Technol. 2015, 175, 128-134. [CrossRef] [PubMed]

48. Adams, J.M.M.; Schmidt, A.; Gallagher, J.A. The impact of sample preparation of the macroalgae Laminaria digitata on the production of the biofuels bioethanol and biomethane. J. Appl. Phycol. 2015, 27, 985-991. [CrossRef]

49. Bledzki, A.K.; Sperber, V.E.; Faruk, O. Natural and Wood Fibre Reinforcement in Polymers; iSmithers Rapra Publishing: Akron, OH, USA, 2002.

50. Ge, L.; Wang, P.; Mou, H. Study on saccharification techniques of seaweed wastes for the transformation of ethanol. Renew. Energy 2011, 36, 84-89. [CrossRef]

51. Ling, A.L.M.; Yasir, S.; Matanjun, P.; Abu Bakar, M.F. Effect of different drying techniques on the phytochemical content and antioxidant activity of Kappaphycus alvarezii. J. Appl. Phycol. 2015, 27, 1717-1723. [CrossRef] 
52. Kim, H.; Ra, C.H.; Kim, S.K. Ethanol production from seaweed (Undaria pinnatifida) using yeast acclimated to specific sugars. Biotechnol. Bioprocess. Eng. 2013, 18, 533-537. [CrossRef]

53. Lee, K.T.; Ofori-Boateng, C. Biofuels: Production Technologies, Global Profile, and Market Potentials. In Sustainability of Biofuel Production from Oil Palm Biomass; Springer: Singapore, 2013; pp. 31-74.

54. Lee, H.J.; Kim, S.J.; Yoon, J.J.; Kim, K.H.; Seo, J.H.; Park, Y.C. Evolutionary engineering of Saccharomyces cerevisiae for efficient conversion of red algal biosugars to bioethanol. Bioresour. Technol. 2015, 191, 445-451. [CrossRef] [PubMed]

55. Yazdani, P.; Zamani, A.; Karimi, K.; Taherzadeh, M.J. Characterization of Nizimuddinia zanardini macroalgae biomass composition and its potential for biofuel production. Bioresour. Technol. 2015, 176, 196-202. [CrossRef] [PubMed]

56. Van der Wal, H.; Sperber, B.L.H.M.; Houweling-Tan, B.; Bakker, R.R.C.; Brandenburg, W.; López-Contreras, A.M. Production of acetone, butanol, and ethanol from biomass of the green seaweed Ulva lactuca. Bioresour. Technol. 2013, 128, 431-437. [CrossRef] [PubMed]

57. Tan, I.S.; Lee, K.T. Enzymatic hydrolysis and fermentation of seaweed solid wastes for bioethanol production: An optimization study. Energy 2014, 78, 53-62. [CrossRef]

58. Puspawati, S.; Ainuri, M.; Nugraha, D.A. The production of bioethanol fermentation substrate from Eucheuma cottonii seaweed through hydrolysis by cellulose enzyme. Agric. Agric. Sci. Procedia 2015, 3, 200-205. [CrossRef]

59. Gao, F.; Gao, L.; Zhang, D.; Ye, N.; Chen, S.; Li, D. Enhanced hydrolysis of Macrocystis pyrifera by integrated hydroxyl radicals and hot water pretreatment. Bioresour. Technol. 2015, 179, 490-496. [CrossRef] [PubMed]

60. Karray, R.; Hamza, M.; Sayadi, S. Evaluation of ultrasonic, acid, thermo-alkaline and enzymatic pre-treatment on anaerobic digestion of Ulva rigida for biogas production. Bioresour. Technol. 2015, 187, 205-213. [CrossRef] [PubMed]

61. Ho, S.H.; Huang, S.W.; Chen, C.Y.; Hasunuma, T.; Kondo, A.; Chang, J.S. Bioethanol production using carbohydrate-rich microalgae biomass as feedstock. Bioresour. Technol. 2013, 135, 191-198. [CrossRef] [PubMed]

62. Khambhaty, Y.; Mody, K.; Gandhi, M.R.; Thampy, S.; Maiti, P.; Brahmbhatt, H.; Eswaran, K.; Ghosh, P.K. Kappaphycus alvarezii as a source of bioethanol. Bioresour. Technol. 2012, 103, 180-185. [CrossRef] [PubMed]

63. Meinita, M.D.N.; Marhaeni, B.; Winanto, T.; Setyaningsih, D.; Hong, Y.K. Catalytic efficiency of sulfuric and hydrochloric acids for the hydrolysis of Gelidium latifolium (Gelidiales, Rhodophyta) in bioethanol production. J. Ind. Eng. Chem. 2015, 27, 108-114. [CrossRef]

64. Ra, C.H.; Jeong, G.T.; Shin, M.K.; Kim, S.K. Biotransformation of 5-hydroxymethylfurfural (HMF) by Scheffersomyces stipitis during ethanol fermentation of hydrolysate of the seaweed Gelidium amansii. Bioresour. Technol. 2013, 140, 421-425. [CrossRef] [PubMed]

65. Meinita, M.D.N.; Marhaeni, B.; Winanto, T.; Jeong, G.T.; Khan, M.N.A.; Hong, Y.K. Comparison of agarophytes (Gelidium, Gracilaria, and Gracilariopsis) as potential resources for bioethanol production. J. Appl. Phycol. 2013, 25, 1957-1961. [CrossRef]

66. Meinita, M.D.N.; Kang, J.Y.; Jeong, G.T.; Koo, H.M.; Park, S.M.; Hong, Y.K. Bioethanol production from the acid hydrolysate of the carrageenophyte Kappaphycus alvarezii (cottonii). J. Appl. Phycol. 2012, 24, 857-862. [CrossRef]

67. Mutripah, S.; Meinita, M.D.N.; Kang, J.Y.; Jeong, G.T.; Susanto, A.B.; Prabowo, R.E.; Hong, Y.K. Bioethanol production from the hydrolysate of Palmaria palmata using sulfuric acid and fermentation with brewer's yeast. J. Appl. Phycol. 2014, 26, 687-693. [CrossRef]

68. Tan, I.S.; Lee, K.T. Solid acid catalysts pretreatment and enzymatic hydrolysis of macroalgae cellulosic residue for the production of bioethanol. Carbohydr. Polym. 2015, 124, 311-321. [CrossRef] [PubMed]

69. Wu, F.C.; Wu, J.Y.; Liao, Y.J.; Wang, M.Y.; Shih, I.L. Sequential acid and enzymatic hydrolysis in situ and bioethanol production from Gracilaria biomass. Bioresour. Technol. 2014, 156, 123-131. [CrossRef] [PubMed]

70. Uju Wijayanta, A.T.; Goto, M.; Kamiya, N. Great potency of seaweed waste biomass from the carrageenan industry for bioethanol production by peracetic acid-ionic liquid pretreatment. Biomass Bioenergy 2015, 81, 63-69. [CrossRef]

71. Quiroz-Castañeda, R.E.; Folch-Mallol, J.L. Hydrolysis of biomass mediated by cellulases for the production of sugars. In Sustainable Degradation of Lignocellulosic Biomass Techniques, Applications and Commercialization; InTech: Vienna, Austria, 2013; pp. 119-155. 
72. Ndimba, B.K.; Ndimba, R.J.; Johnson, T.S.; Waditee-Sirisattha, R.; Baba, M.; Sirisattha, S.; Shiraiwa, Y.; Agrawal, G.K.; Rakwal, R. Biofuels as a sustainable energy source: An update of the applications of proteomics in bioenergy crops and algae. J. Proteom. 2013, 93, 234-244. [CrossRef] [PubMed]

73. Bhatia, L.; Johri, S.; Ahmad, R. An economic and ecological perspective of ethanol production from renewable agro waste: A review. AMB Express 2012, 2, 65. [CrossRef] [PubMed]

74. Bilan, M.I.; Grachev, A.A.; Shashkov, A.S.; Nifantiev, N.E.; Usov, A.I. Structure of a fucoidan from the brown seaweed Fucus serratus L. Carbohydr. Res. 2006, 341, 238-245. [CrossRef] [PubMed]

75. Ra, C.H.; Kang, C.H.; Jeong, G.T.; Kim, S.K. Bioethanol production from the waste product of salted Undaria pinnatifida using laboratory and pilot development unit (PDU) scale fermenters. Biotechnol. Bioprocess. Eng. 2014, 19, 984-988. [CrossRef]

76. Ra, C.H.; Kim, S.K. Optimization of pretreatment conditions and use of a two-stage fermentation process for the production of ethanol from seaweed, Saccharina japonica. Biotechnol. Bioprocess. Eng. 2013, 18, 715-720. [CrossRef]

77. Yoon, M.; Choi, J.; il Lee, J.W.; Park, D.H. Improvement of saccharification process for bioethanol production from Undaria sp. by gamma irradiation. Radiat. Phys. Chem. 2012, 81, 999-1002. [CrossRef]

78. Meillisa, A.; Woo, H.C.; Chun, B.S. Production of monosaccharides and bio-active compounds derived from marine polysaccharides using subcritical water hydrolysis. Food Chem. 2015, 171, 70-77. [CrossRef] [PubMed]

79. Sarkar, N.; Ghosh, S.K.; Bannerjee, S.; Aikat, K. Bioethanol production from agricultural wastes: An overview. Renew. Energy 2012, 37, 19-27. [CrossRef]

80. Tan, I.S.; Lam, M.K.; Lee, K.T. Hydrolysis of macroalgae using heterogeneous catalyst for bioethanol production. Carbohydr. Polym. 2013, 94, 561-566. [CrossRef] [PubMed]

81. Ahring, B.K.; Jensen, K.; Nielsen, P.; Bjerre, A.B.; Schmidt, A.S. Pretreatment of wheat straw and conversion of xylose and xylan to ethanol by thermophilic anaerobic bacteria. Bioresour. Technol. 1996, 58, 107-113. [CrossRef]

82. Neves, M.A.; Kimura, T.; Shimizu, N.; Nakajima, M. State of the art and future trends of bioethanol production. Dyn. Biochem. Process. Biotechnol. Mol. Biol. 2007, 1, 1-14.

83. Kim, E.J.; Fathoni, A.; Jeong, G.T.; Jeong, H.; Do Nam, T.J.; Kong, I.S.; Kim, J.K. Microbacterium oxydans, a novel alginate- and laminarin-degrading bacterium for the reutilization of brown-seaweed waste. J. Environ. Manag. 2013, 130, 153-159. [CrossRef] [PubMed]

84. Kim, D.H.; Lee, S.B.; Jeong, G.T. Production of reducing sugar from Enteromorpha intestinalis by hydrothermal and enzymatic hydrolysis. Bioresour. Technol. 2014, 161, 348-353. [CrossRef] [PubMed]

85. Ota, A.; Kawai, S.; Oda, H.; Iohara, K.; Murata, K. Production of ethanol from mannitol by the yeast strain Saccharomyces paradoxus NBRC 0259. J. Biosci. Bioeng. 2013, 116, 327-332. [CrossRef] [PubMed]

86. Abbi, M.; Kuhad, R.C.; Singh, A. Bioconversion of pentose sugars to ethanol by free and immobilized cells of Candida shehatae (NCL-3501): Fermentation behaviour. Process Biochem. 1996, 31, 555-560. [CrossRef]

87. Takagi, T.; Uchida, M.; Matsushima, R.; Kodama, H.; Takeda, T.; Ishida, M.; Urano, N. Comparison of ethanol productivity among yeast strains using three different seaweeds. Fish Sci. 2015, 81, 763-770. [CrossRef]

88. Talebnia, F.; Karakashev, D.; Angelidaki, I. Production of bioethanol from wheat straw: An overview on pretreatment, hydrolysis and fermentation. Bioresour. Technol. 2010, 101, 4744-4753. [CrossRef] [PubMed]

89. Boldrin, A.; Karakashev, D.B.; Holdt, S.L.; Angelidaki, I.; Astrup, T. Life Cycle Assessment of biofuel production from Laminaria digitata in Danish conditions. Bioresour. Technol. 2013, 129, 92-99.

90. Aitken, D.; Bulboa, C.; Godoy-Faundez, A.; Turrion-Gomez, J.L.; Antizar-Ladislao, B. Life cycle assessment of macroalgae cultivation and processing for biofuel production. J. Clean. Prod. 2014, 75, 45-56. [CrossRef]

91. Fasahati, P.; Liu, J. Industrial-scale bioethanol production from brown algae and economic comparison of two pretreatment designs. Comput. Aided Chem. Eng. 2014, 34, 507-512. [CrossRef]

(C) 2018 by the authors. Licensee MDPI, Basel, Switzerland. This article is an open access article distributed under the terms and conditions of the Creative Commons Attribution (CC BY) license (http://creativecommons.org/licenses/by/4.0/). 